\title{
CLIMATE CHANGE AND ITS IMPACTS ON WORLD'S CULTURAL HERITAGE
}

\section{Svetlana Marković}

Belgrade Business School - Higher

Education Institution for Applied Studies,

Belgrade, Serbia
Correspondence:

Svetlana Marković

e-mail:

svetlana_markovic2003@yahoo.com
Abstract:

Global climate change is a serious threat to humanity and cultural heritage which represents the most reliable witness of historical processes and global cultural evolution, as well as the vital element for tourism product differentiation in many destination areas worldwide. Global climate change can influence cultural heritage through the impacts of tornadoes, hurricanes and storms, sea level rise, floods, tides and avalanches and extreme temperatures, fires and droughts. This paper explores the relationship between climate change and global cultural heritage, illustrated by examples of previous natural disasters and events, and presents certain future predictions based on the current scientific knowledge.

Keywords:

climate change, cultural heritage, tourism risk managment, adaptation measures

\section{INTRODUCTION}

Climate change impact on cultural heritage in many ways: through storms, floods, sea level rise, extreme temperatures, fires or droughts (Jigyasu et al., 2013; Sabbioni et al., 2010; Wang, 2015). The main conclusions of Intergovernmental Panel on Climate Change in 1990, 1995, 2001 and 2007, organized by World Meteorological Organization and the United Nations Environmental Programme highlighted the extent of the anthropogenic contributions to the evidenced climate change. The natural disasters associated with climate change pose a serious threat for tangible forms of cultural heritage. As defined in the Article 1 of the United Nations Educational, Scientific and Cultural Organisation Convention (Unesco, 1980), cultural heritage refers to moveable, tangible heritage items such as art paintings, sculptures, coppers, coins and manuscripts; immovable heritage, such as monuments, archaeological sites and underwater cultural heritage such as shipwrecks, underwater ruins and cities; and intangible items including oral traditions, performing arts and rituals (ANU, 2009). The largest number of climate-associated risks is related to the immovable heritage such as archaeological sites, cultural landscapes, buildings and UNESCO World Heritage sites (Mazurczyk et al., 2018). Cultural heritage has a historical, aesthetic, social, scientific and spiritual value recognized by the past, present and future generations and as such is a witness of historical events and cultural evolution (Dirk, 1999). 


\section{THE IMPACT OF NATURAL DISASTERS ON TOURISM AND CULTURAL HERITAGE}

\section{Tropical storms as a consequence of climate change}

Cultural heritage can be affected by tropical storms, most often occurring when the surface temperature of the ocean is reaching $27-30^{\circ} \mathrm{C}$, which is above the average value of $24^{\circ} \mathrm{C}$. Scientists claim that tropical storms have shifted for more than $50 \mathrm{~km}$ outside their usual belt every decade over the past 30 years. The trend is particularly noticeable in the Pacific and the Indian Ocean. It has been known that global warming enhances the chances for tropical storms, and one of the factors that can lead to serious consequence is a steady rise in sea levels, putting coastal parts of the world in even greater danger when storms occur. There are various kinds of tropical storms that carry different names. Depending on their speed and locations where they occur, they are called hurricanes and typhoons. Hurricane is a type of tropical storm with blowing speed that exceeds $119 \mathrm{~km} / \mathrm{h}$. It is mostly formed in the Gulf of Mexico from where it spreads with varying intensity to the southeastern part of the United States of America or the Caribbean countries. Typhoon is a type of tropical cyclone typical for the northwestern part of the Pacific, with the wind speed reaching up to $300 \mathrm{~km} / \mathrm{h}$ in its center. Typhoons account for one third of the total number of tropical cyclones on the Earth, and their main location is bordered by the shore of East Asia, the equator in the South and the International Date Line in the East. Hurricanes and typhoons usually appear during the summer and autumn.

\section{Extreme temperatures and wildfires as a consequence of climate change}

The consequences on cultural heritage can also be caused by wildfires from extreme temperatures. Global Climate Observing System classified fire disturbance as an "essential climate variable", it has emphasized the need for long data time series to quantify the links between climate and fire (WMO, 2006).

\section{Floods as a consequence of climate change}

Floods are most often defined as an unpredictable natural disaster that includes abundant rain, spring tides and typhoons (Wang, 2015). Floods cause a direct damage to historical sculptures, buildings and other cultural heritage by damaging its structure, foundation and underground part (Siedel, 2010; Válek et al., 2010). The frequency, volume, unpredictability of floods and their ability to destroy the environment have increased with global climate change. (Tutunaru et al., 2013).

\section{Rising sea level as a consequence of climate change}

Over the last century, the average global temperature increased by $0.6^{\circ} \mathrm{C}$, while at the end of the century the global air temperature could be expected to raise by $3{ }^{\circ} \mathrm{C}$, which could cause melting of Greenland ice cover (Perez-Alvaro, 2016). Sea levels are rising not only because of ice melting, but also because of thermal expansion, refering to the fact that warmer water occupies more space than cold water. The rise of sea level leads to coastal retreat. For example, the rise of $1 \mathrm{~mm}$ in sea level leads to coastal retreat by $1.5 \mathrm{~m}$. The average global sea level has risen by an average rate of $1.8 \mathrm{~mm} /$ year (1.3 to 2.3 ) since 1961, and $3.1 \mathrm{~mm} /$ year (2.4 to 3.8 ) since 1993. By 2100 , climate change could potentially induce the sea level rise that would overflow 136 locations that UNESCO regards as cultural and historical treasures (Perez-Alvaro, 2016). To remind, large number of megacities are located on the coast.

The following pictures from Climate Central (2015) indicate forecasts of the future appearance of large world cities that could be affected by the sea level rise caused by the increase in global air temperature. Pictures on the left represent potencial consequences of the increase in global air temperature by $2^{\circ} \mathrm{C}$, and the pictures on the right show the cosequences of the increase of $4^{\circ} \mathrm{C}$. (see Pic. 1-4). 
Picture 1. London (UK)

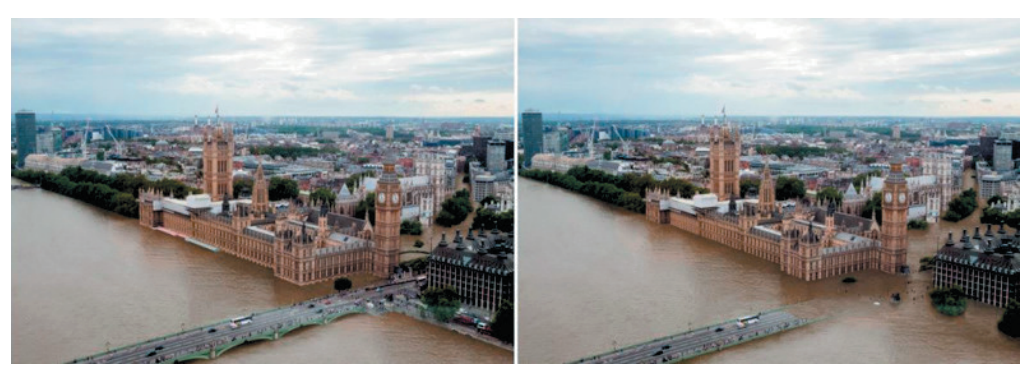

Source: (C[Climate Central]. http://sealevel.climatecentral.org; (Perez-Alvaro, 2016).

Picture 2. New York (USS)

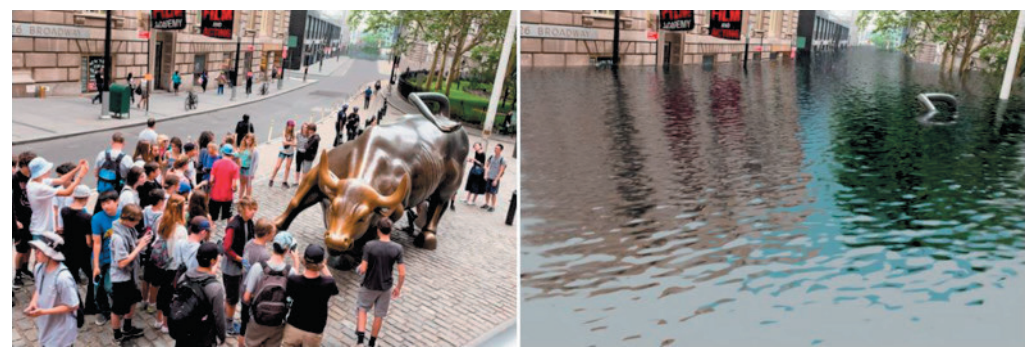

Source: (ㄷ [Climate Central]. http://sealevel.climatecentral.org; (Perez-Alvaro, 2016).

Picture 3. Rio de Janerio (Brazil)
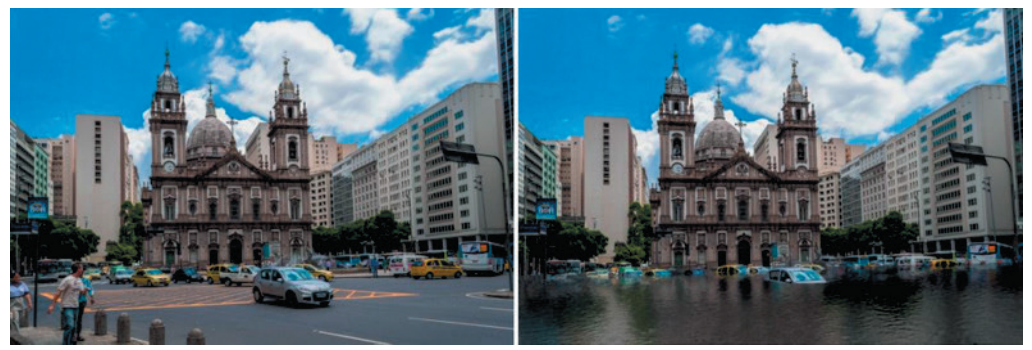

Source: ()[Climate Central]. http://sealevel.climatecentral.org; (Perez-Alvaro, 2016).

Picture 4. Sydney (Australia)
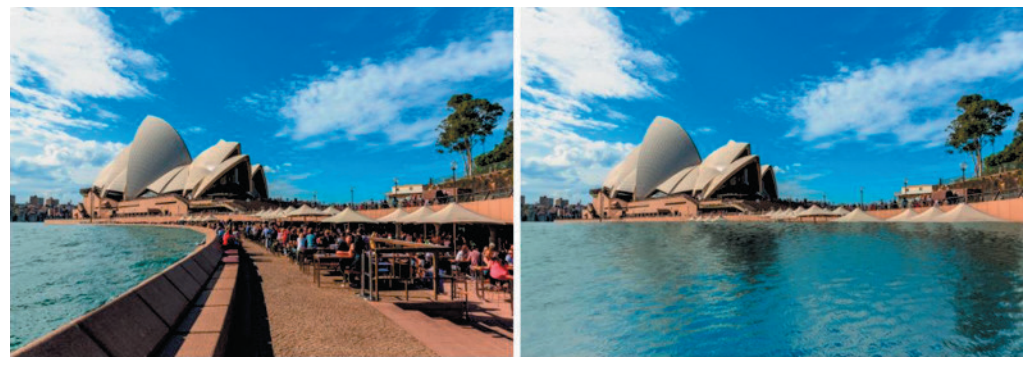

Source: (ㅇ [Climate Central]. http://sealevel.climatecentral.org; (Perez-Alvaro, 2016). 


\section{THE IMPACT OF CLIMATE CHANGE ON THE WORLD'S CULTURAL HERITAGE}

The appearance of the most recognizable and most sacred world cultural heritage is endangered by the possible consequences that cause climate change, the United Nations Educational, Scientific and Cultural Organization (UNESCO) claimed in an official document known as "World Heritage and Tourism in a Changing Climate" (2016). It indicated that so far at 31 locations of world cultural heritage in 29 countries, global climate change has manifested its consequences after increasing temperatures, wildfires, intensifying tropical storms, melting glaciers, floods and risig sea level.

In one of the world's largest tourist destinations - the city of Venice, there is an increase in the sea level that changes the initial appearance of the city and all the cultural buildings it owns. The sculptures are peeling and mosaics in the St. Mark's Basilica slowly dissolve. Statue of Liberty in New York was damaged after superstorm Sandy. Statues of Easter Island are threatened when large waves occur, and it is also predicted that Stonehenge will be at risk in the future (Davidson Sorkin, 2016).

In Finland, 160 kilometers from Helsinki is "Verla" factory, which is classified in the list of UNESCO world cultural heritage representing rural industrial production of wood pulp and paperboard. As the sea level rise, and due to heavy rain - water from the Gulf of Finland threatens to flood factory and the level of water is raised above the mill (Picture 5). Prevention measures have been taken, although there is still a risk of flooding (Kaslegard, 2011).

Picture 5. Flooded factory building, Verla ; Photo: Pertti Peltola, Verla Mill Museum

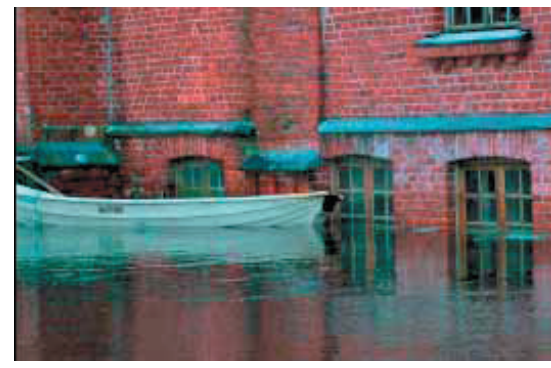

Source: (Kaslegard, 2011)

Kirkjubøur is the seat of the bishop on the Faroe Islands. As it is located on the coast of the sea, due to natural disasters (rising sea levels and coastal erosion), this episcopacy- which represents a unique cultural heritage, has often been endangered in its history (Picture 6). With the rise of the sea level, the remnants of this episcopacy will be significantly put at risk. In 2008, a policy for the preservation of the site was implemented. Various forms of coastal defense are included here, and the basic precondition is to record areas vulnerable to erosion - in order to save valuable places of cultural heritage so it could't be lost (Kaslegard, 2011).

Picture 6. Kirkjubøur with the remains of Líkhús church in the foreground, the white parish church to the left, and the ruins of Magnus Cathedral to the right; Photo: Símun V. Arge, 
The most prevalent floods that have left a great mark on cultural heritage over the last few decades were (Deschaux, 2017):

Floods in Florence (Italy) on November $4^{\text {th }}, 1966$ when the Arno River flooded the city in two days - sludge and water burst into churches, museums and libraries and UNESCO confirmed that the flood damaged $885 \mathrm{im}$ portant works of art, 18 religious objects, several dozen items, 70 libraries, scientific institutions and more than 70,000 archives with about 50 million items, out of which 10,000 were of immense historical or scientific value.

Nîmes flood, Gard (France) on October $3^{\text {rd }}$, 1988. - the main Roman landmarks were mostly preserved, but the Departmental Archives of Gard was damaged.

Vaison-la-Romaine flood, Vaucluse (France) on September 22 ${ }^{\text {nd }}$, 1992. - the medieval sites including the Cathédrale de Notre Dame, the Nazareth and Chapelle Saint-Quenin, and the Château des Comtes de Toulouse have also been damaged by the sludge penetrating into their interior.

Municipal Archaeological Repository flood, Marseille, Bouches-du-Rhône (France) on September 19 ${ }^{\text {th }}$, 2000.

Prague flood (Czech Republic) on August, 2002. - the floods have damaged many libraries and archive centers. At that time, the library at the Archaeological Institute lost 70,000 books - 60,000 books were damaged in the municipal library in Prague, and libraries at the Institute of Sociology and Philosophy, Academy of Sciences and Czech Philharmonic were also affected. A total of 45 libraries were damaged by floods, and over 600,000 works were irretrievably lost.

The floods in central France on May-June, 2016: Château de Chambord flood, a castle in the Loire Valley, which dates from the 16th century.

\section{CONCLUSION}

The World Cultural Heritage is a key element of the world's nation identity, therefore great effort is being made in order to preserve it, especially its quality, duration and material structures protections. Cultural heritage has been increasingly exposed to the effects of climate change - endangering its identity, the cultural and universal values it represents. Climate change risks such as the sea level rises, floods, fires and stormy winds, etc., (which impact will lead to its irreversible destruction), - has moved the international community to launch initiatives trying to find a solution to this problem. Planning the adaptation of cultural heritage to climate change includes several steps such as identification of vulnerabilities, data collection and risk assessment, developing options for the adjustment process, implementation possibilities, and monitoring and evaluation of the implementation of the adaptation measures (Bierbaum et al., 2013, IPCC, 2014, Moser and Ekstrom, 2010). Many activities are carried out before applying the adaption measures and some of them are raising social awareness, developing technological innovations, implementing the current knowledge, cooperation with industry and thinking about further decisions in case of uncertainty. Disaster management focusing on cultural heritage has increased worldwide since the 1990s.

\section{REFERENCES}

ANU (2009). Implications of climate change for Australia's world heritage properties: a preliminary assessment (Research report), edited by the Australian National University Fenner School of Environment and Society, Canberra.

Bierbaum R., Smith J., Lee A., Blair M., Carter L., Chapin F.S.I., Fleming P., Fuffo S., Stults M., McNeeley S., Wasley E., \& Verduzco L. (2013). A comprehensive review of climate adaptation in the United States: more than before, but less than needed. Mitigat. Adapt. Strat. Global Change, 18 (2013), pp. 361-406.

Davidson Sorkin, A. (2016). How climate change will destroy our global heritage. The New Yorker. Retrieved March 12, 2018 from https://www.newyorker.com/news/amy-davidson/how-climate-change-will-destroy-our-global-heritage

Deschaux, J. (2017). Flood-related Impacts on Cultural Heritage. Floods, Volume 1, Risk Knowledge, DOI:10. 1016/B978-1-78548-268-7.50004-3 
Dirk, H.R.S. (1999). Cultural heritage conservation during emergency management: luxury or necessity? Inernational Journal of Public Administration, 22(5), 745-804. DOI:10.1080/01900699908525403

Intergovernmental Panel on Climate Change (2014). Climate Change 2014: Impacts, Adaptation and Vulnerability. Cambridge: Cambridge University Press.

Jigyasu R., Murthy M., Boccardi G., Marrion C., Douglas D., King J., O’Brien G., Dolcemascolo G., Kim Y., Albrito P. (2013). Heritage and Resilience: Issues and Opportunities for Reducing Disaster Risks. Retrieved March 12, 2018 from https://www.unisdr.org/we/inform/publications/33189

Kaslegard, A.S. (2011) Climate change and cultural heritage in the Nordic countries. Copenhagen: Nordic Council of Ministers.

Mazurczyk, T., Piekielek, N., Tansey, E., Goldman, B. (2018). American archives and climate change: Risks and adaptation. Climate Risk Menagment, 20, 111-125.

Moser, S.C., Ekstrom, J.A. (2010). A framework to diagnose barriers to climate change adaptation. Proceedings of the National Academy of Sciences of the United States 107(51), 22026-22031. DOI:10.1073/pnas. 1007887107

Perez-Alvaro, E. (2016). Climate change and underwater cultural heritage: Impacts and challenges. Journal of Cultural Heritage, 21, 842-848.

Sabbioni, C., Brimblecombe, P., \& Cassar, M. (2010). The atlas of climate change impact on European cultural heritage. Scientific Analysis and Management Strategies, Anthem Press.

Siedel, H. (2010). Historic building stones and flooding: changes of physical properties due to water saturation. J. Perform. Journal of Performance of Constructed Facilities, 24(5), 452-461.

Strauss, B.H.Kulp, S., \& Levermann, A. (2015). Mapping Choices: Carbon, Climate and Rising Seas, Our Global Legacy. Climate Central Research Report. pp.1-38. Retrieved March 12, 2018 from http://sealevel.climatecentral.org/uploads/research/Global-Mapping-Choices-Report.pdf

Tutunaru, I.D., Blidaru, T.V., Pricop, I.C. (2013). The assessment of the cultural heritage's vulnerability to flash floods in Bahlui river basin, Iasi county. European Journal of Science and Theology, 9(2), 233-242.

UNESCO. (1980). Convention concerning the Protection of the World Cultural and Natural Heritage: Adopted by the General Conference at its seventeenth session, Paris, 16 November 1972. Paris: Unesco.

Válek J., Kruschwitz S., Wöstmann J., Kind T., Valach J., Köpp C., Lesák J. (2010). Nondestructive investigaton of wet building material. multimethodical approach. Journal of Performance of Constructed Facilities, 24(5), 462-472

Wang, J.J. (2015). Flood risk maps to cultural heritage: Measures and process. Journal of Cultural Heritage, $16(2), 210-220$.

WMO. (2006). Systematic observation requirements for satellite-based products for climate-supplemental details to the satellite-based component of the "Implementation Plan for the Global Observing System for Climate in Support of the UNFCCC". Retrieved March 12, 2018 from https://library.wmo.int/index. php?lvl=notice_display\&id=12835 